\title{
Myopic Loss Aversion dan Literasi Keuangan Pada Pengambilan Keputusan Investor Pemula Indonesia
}

\section{Myopic Loss Aversion and Financial Literacy in Indonesian Beginner Investor Decision Making}

\author{
Andi Fauziah \\ Program Studi Magister Manajemen, Fakultas Ekonomi dan Manajemen, IPB University, Dramaga, Bogor 16680 \\ e-mail: fauziah_andi@apps.ipb.ac.id \\ Budi Purwanto* \\ Program Studi Magister Manajemen, Fakultas Ekonomi dan Manajemen, IPB University, Dramaga, Bogor 16680 \\ e-mail: budipurwanto@apps.ipb.ac.id \\ Wita Juwita Ermawati \\ Departemen Manajemen, Fakultas Ekonomi dan Manajemen, IPB University, Dramaga, Bogor 16680 \\ e-mail: wiet_07@yahoo.com
}

\begin{abstract}
Risk averse behavior are psychological barriers for investor to join the capital market. Risk averse behavior will restrict the investor financial decision, so it needs to be anticipated through improving financial literacy. Low financial literacy increases the evaluation frequency, hence the risk averse behavior will increased and reduce the return. This problem can be prevented by increasing financial literacy so that the investor will behave as a risk seeker and increase the return. This paper aims to examine factors that are affected the investor returns. Multiple linear regression analyses using SPSS 20 was utilized to see the effect of financial literacy, evaluation frequency, maxhold, investment duration, technical analysis, and fundamental analysis against return increasing. The results showed that financial literacy and investment durations were positively significant towards investor returns, the use of technical analysis negatively significant towards investor returns, while insufficient evidence to Indicates that the frequency of evaluation, max hold, and the use of fundamental analysis affects investors returns at a 90 percent confidence level.
\end{abstract}

Keywords: financial literacy, frequency of evaluation, investment duration, myopic loss aversion, return, technical analysis.

\section{ABSTRAK}

Hambatan seseorang bergabung dalam pasar modal adalah hambatan psikologis, yaitu perilaku risk averse. Perilaku risk averse akan membatasi pelaku pasar modal untuk mengambil keputusan, sehingga perlu diantisipasi melalui peningkatan literasi keuangan. Literasi keuangan yang rendah akan meningkatkan frekuensi evaluasi, sehingga akan meningkatkan perilaku risk averse dan menurunkan return. Permasalahan ini dapat dicegah dengan meningkatkan literasi keuangan sehingga pelaku pasar modal akan berperilaku risk seeker dan meningkatkan return. Penelitian ini bertujuan untuk menguji faktor-faktor yang berpengaruh terhadap return investor. Analisis regresi linear berganda menggunakan SPSS 20 untuk melihat pengaruh literasi keuangan, frekuensi evaluasi, maxhold, durasi investasi, penggunaan analisis teknikal, dan penggunaan analisis fundamental terhadap peningkatan return. Hasil yang diperoleh menunjukkan bahwa literasi keuangan dan durasi investasi berpengaruh signifikan positif terhadap return investor, penggunaan analisis teknikal berpengaruh signifikan negatif terhadap return investor, sedangkan belum cukup bukti untuk menunjukkan bahwa frekuensi evaluasi, maxhold, dan penggunaan analisis fundamental berpengaruh terhadap return investor pada tingkat kepercayaan 90 persen.

Kata Kunci: analisis teknikal, durasi investasi, frekuensi evaluasi, literasi keuangan, return 


\section{PENDAHULUAN}

Investasi pasar modal memegang peranan penting bagi perekonomian suatu negara, sebab menjalankan fungsi ekonomi dan juga fungsi keuangan (Pakpahan, 2003). Fungsi ekonomi yaitu mempertemukan pihak berkelebihan dana (investor) dengan pihak yang membutuhkan dana (issuer). Pertemuan kedua pihak ini akan memberikan fungsi keuangan berupa return bagi investor dan tambahan dana bagi issuer. Pentingnya peranan ini belum didukung oleh tingkat inklusi dan literasi keuangan sektor pasar modal. Survei OJK (2016) menunjukkan bahwa inklusi keuangan pasar modal terendah dibandingkan dengan sektor keuangan lainnya, yaitu hanya 1,25 persen, sehingga upaya untuk meningkatkan minat masyarakat untuk bergabung ke pasar modal adalah suatu hal yang penting.

Pemerintah telah melakukan berbagai upaya untuk meningkatkan inklusi keuangan sektor pasar modal, diantaranya yaitu Edukasi Pasar Modal Syariah, Kampanye Yuk Nabung Saham, dan pembukaan Galeri Investasi. Peningkatan inklusi keuangan ini disertai dengan upaya peningkatan literasi keuangan untuk mempersiapkan para calon investor dalam menjalankan kegiatan di pasar modal. Pendirian galeri investasi bertujuan untuk mendekatkan bursa pasar modal kepada masyarakat khususnya civitas akademika. Pendampingan berupa pelatihan rutin setiap periode juga dilaksanakan untuk meningkatkan literasi keuangan nasabah. Namun hasil yang didapatkan belum maksimal, nasabah dengan pembekalan literasi masih belum sepenuhnya berani dan optimal dalam pengambilan keputusan investasinya. Hal ini mengindikasikan adanya faktor lain yang menghambat pengambilan keputusan investasi para investor pemula Indonesia.

Pengambilan keputusan investasi tidak hanya dipengaruhi oleh literasi keuangan, terdapat pengaruh psikologi yang juga tidak dapat diabaikan. Behavioral finance merupakan cabang baru dari analisis pasar modal dengan mempertemukan disiplin ekonomi dan juga psikologis (Goldberg \& Nitzch, 2001). Richard H. Thaler seorang ekonom asal Amerika Serikat berhasil mendapatkan nobel ekonomi tahun 2017 atas kontribusinya terhadap behavioral economics. Salah satu penelitiannya menjelaskan tentang adanya myopic loss aversion dalam pengambilan keputusan investor. Thaler (1997) menjelaskan adanya ketakutan akan kerugian yang lebih tinggi dibandingkan keinginan mendapatkan keuntungan apabila dipengaruhi oleh evaluasi outcome. Pelaku pasar modal dengan frekuensi evaluasi lebih tinggi akan lebih cenderung menolak risiko. Penelitian ini diperkuat oleh Gneezy dan Potters (1997) yang menemukan bahwa investor dengan frekuensi evaluasi return yang tinggi, memiliki perilaku risk averse dan memiliki return rendah.

Pengujian myopic loss aversion lainnya juga telah dilakukan oleh beberapa peneliti terdahulu seperti Gnezzy et al. (2003) dan Bellemare et al. (2005). Mereka menemukan bahwa pada frekuensi evaluasi yang tinggi, penanam saham akan mengalami loss aversion sehingga saham hanya dimiliki dalam jangka waktu yang pendek. Perilaku ini perlu dimitigasi dengan mengurangi frekuensi evaluasi atau melakukan evaluasi return dengan periode yang lebih panjang. Periode evaluasi yang lebih panjang akan meningkatkan minat penanam saham untuk memilih produk investasi yang berisiko. Zeiberger et al. (2007) membuktikan adanya myopic loss aversion pada pemilihan produk investasi. Apabila periode evaluasi dilakukan pada periode empat bulan maka investor akan lebih memilih obligasi, sedangkan pada periode 34 bulan investor akan lebih memilih investasi pada saham dibandingkan obligasi meskipun saham merupakan produk investasi yang berisiko. Frekuensi evaluasi return menjadi hal yang sangat penting dalam pencegahan myopic loss aversion.

Frekuensi evaluasi return yang tinggi erat hubungannya dengan penggunaan analisis teknikal dalam pengambilan saham. Analisis teknikal merupakan cara memprediksi harga saham dengan memperhatikan pergerakan harga saham setiap detik, setiap hari, setiap minggu, atau setiap bulan untuk melihat kecenderungan pergerakan naik turunnya harga saham di waktu yang akan datang (Samsul, 2015). Gneezy dan Potters (1997) mengemukakan bahwa evaluasi investasi secara agregat akan mengurangi ketakutan akan risiko, serta meningkatkan penghasilan pelaku pasar modal. Evaluasi agregat dapat dilakukan dengan melakukan analisis 
saham secara lengkap mulai dari analisis ekonomi makro, analisis fundamental, dan analisis teknikal.

Sebelum menggunakan analisis, pelaku pasar modal tentunya harus dibekali oleh literasi keuangan terkait analisis saham tersebut. Sehingga konsep literasi keuangan menjadi sesuatu yang penting. Literasi keuangan yang tinggi akan memberikan kontribusi besar bagi kesejahteraan keuangan individu sebab akan memungkinkan untuk berpartisipasi di pasar keuangan dan berkinerja lebih baik di pilihan portofolio mereka (Rooij et al., 2011). Sesuai dengan new literation study (NLS), literasi keuangan merupakan sesuatu yang dinamis tergantung dari kondisi sosial yang diamati (Street, 2003), sehingga definisi literasi keuangan berbeda-beda tergantung individu atau kelompok yang diamati. Kuesioner literasi keuangan OECD yang mengeneralisasi menjadi kurang relevan sehingga diperlukan instrumen pengukuran baru yang lebih relevan.

Penelitian ini bertujuan untuk membuat suatu instrumen pengukuran literasi keuangan baru dan lebih relevan, lalu kemudian mengukur apakah literasi keuangan berpengaruh terhadap pengambilan keputusan investor dalam hal ini direpresentasikan dalam bentuk return. Selain faktor literasi keuangan, penelitian ini juga menguji faktor psikologis yang memperngaruhi perolehan return investor.

\section{METODE PENELITIAN}

Perilaku risk averse akan membatasi pelaku pasar modal untuk mengambil keputusan, sehingga perlu diantisipasi melalui peningkatan literasi keuangan. Literasi keuangan yang rendah akan membatasi investor untuk hanya menggunakan analisis teknikal yang identik dengan tingginya frekuensi evaluasi, sehingga akan meningkatkan perilaku risk averse dan mengurangi perolehan return. Permasalahan ini dapat dicegah dengan meningkatkan literasi keuangan sehingga pelaku pasar modal akan meminimalisir penggunaan analisis teknikal dengan diimbangi analisis lainnya dan meningkatkan perolehan return. Peningkatan literasi keuangan juga harus didukung oleh pengalaman berinvestasi yang diperoleh selama bergabung di pasar modal, sehingga durasi bergabung dengan pasar modal (durasi investasi) menjadi faktor yang berpengaruh. Penelitian ini akan melihat pengaruh literasi keuangan, frekuensi evaluasi, maxhold, durasi investasi, penggunaan analisis teknikal, dan penggunaan analisis fundamental terhadap peningkatan return.

Populasi dalam penelitian adalah anggota dua galeri investasi (GI) yaitu Universitas Kristen Maranatha dan STIE Trisakti. Pemilihan kedua galeri investasi didasarkan atas keberhasilan kedua galeri tersebut dalam mendapatkan penghargaan sebagai Galeri Investasi BEI terbaik kategori nilai transaksi peringkat pertama dan kedua pada tahun 2018. Penghargaan yang diperoleh menunjukkan bahwa kedua galeri investasi tersebut merupakan galeri investasi aktif dengan performa tinggi. Pengambilan sampel menggunakan teknik convenience sampling hingga didapatkan hasil yang signifikan. Convenience sampling sangat tepat untuk digunakan pada penelitian dengan kelompok yang terfokus serta pengujian awal dari suatu hipotesis (Cresswell, 2007). Data yang digunakan pada penelitian ini merupakan data transaksi pribadi responden, sehingga beberapa anggota dari populasi tidak bersedia untuk menjadi responden. Maka dari itu sampel penelitian terbatas pada anggota populasi yang bersedia memberikan akses terhadap datanya. Data yang digunakan adalah data primer yang diperoleh melalui penyebaran kuesioner kepada anggota galeri investasi yang terdiri dari:

1. Data historis saham, didapatkan dari gmail trade confirmation responden kemudian dirapihkan menjadi format beli dan jual untuk memudahkan proses perhitungan return.

2. Frekuensi evaluasi. Pada kuesioner ditanyakan frekuensi evaluasi saham hari ini, satu minggu terakhir, satu bulan terakhir, serta tiga bulan terakhir. Ditanyakan dalam beberapa rentang waktu untuk menghindari adanya kejadian tidak biasa yang akan membiaskan hasil, sehingga empat rentang waktu tersebut akan menghasilkan rata-rata terbobot yang lebih robust. 
3. Kuesioner literasi keuangan disusun dengan memodifikasi revisi taksonomi bloom yang dikembangkan oleh Anderson et al. (2001). Enam tingkatan yang dikembangkan oleh Anderson et al. (2001) disederhanakan menjadi tiga tingkatan. Tingkatan pertama yaitu remember dan understand, tingkatan kedua yaitu apply dan analyze, serta tingkatan ketiga yaitu evaluate dan create. Masing-masing analisis (ekonomi makro, fundamental, dan teknikal) terdiri dari 12 pertanyaan, yaitu masing-masing tiga pertanyaan untuk setiap tingkatan.

Penelitian ini menghipotesiskan bahwa literasi keuangan yang diukur dengan instrumen yang tepat akan menunjukkan signifikannya pengaruh literasi keuangan terhadap perolehan return. Selain literasi keuangan, faktor durasi investasi juga akan berpengaruh signifikan positif terhadap perolehan return sebab pengalaman akan melatih kemampuan pengambilan keputusan investasi. Penggunaan analisis teknikal akan berpengaruh signifikan negatif terhadap perolehan return sebab akan membatasi kemampuan pengambilan keputusan investasi, sehingga perlu didukung oleh penggunaan analisis lainnya yang bersifat lebih agregat. Faktor psikologis berupa myopic loss aversion dihipotesiskan tidak terjadi pada penelitian ini yaitu ditunjukkan dengan tidak signifikannya pengaruh frekuensi evaluasi terhadap perolehan return. Hal ini terjadi karena penelitian dilakukan pada investor pemula Indonesia yaitu anggota galeri investasi.

\section{HASIL DAN PEMBAHASAN}

Pengujian validitas dilakukan untuk mengukur ketepatan pertanyaan dalam kuesioner, apakah pertanyaan pada kuesioner telah tepat dalam mengukur apa yang ingin diukur. Pengujian validitas dalam penelitian ini dilakukan dengan one shot method atau internal consistency dimana kuesioner diberikan satu kali kepada responden kemudian data dianalisa (Pratisto, 2004). Apabila pertanyaan dinyatakan valid maka dipakai untuk pembahasan selanjutnya dan jika pertanyaan tidak valid pertanyaan tersebut diabaikan atau dibuang.

Metode pengujian validitas yang digunakan adalah pearson product moment yaitu pengujian terkait ada atau tidaknya hubungan antara variabel independen (X) dengan variabel dependen (Y). Jika nilai chi-square hitung > chi-square tabel atau nilai signifikansi < 0,05. Maka interpretasi kesimpulan yaitu cukup bukti bahwa terdapat hubungan antar variabel dengan selang kepercayaan 95 persen, atau dapat dinyatakan bahwa instrumen pertanyaan berkorelasi signifikan terhadap skor total (dinyatakan valid). Pertanyaan dalam penelitian ini dapat dinyatakan valid yaitu tepat dalam mengukur tujuan kuesioner, seperti disajikan dalam Tabel 1 , seluruh variabel memiliki signifikansi dibawah 0,5 .

Uji reliabilitas berguna untuk mengetahui keandalan dari instrumen yang digunakan. Kuesioner yang reliabel adalah kuesioner yang dapat digunakan oleh siapa saja dan kapan saja. Penelitian ini menggunakan uji statistik cronbach alpha dengan SPSS. Ghozali (2007) menyatakan bahwa suatu konstruk atau variabel dinyatakan reliabel jika nilai cronbach alpha > 0,60 . Metode pengujian yang digunakan adalah pearson product moment, variabel dianggap valid apalah signifikansinya $<0,05$, sehingga seluruh variabel literasi keuangan yang digunakan dalam penelitian ini telah reliabel.

Tabel 1. Hasil uji validitas

Jurnal Manajemen da Organisasi (JMO),
Vol. 11 No. 1, April 2020, Hal. 1-7

\begin{tabular}{lc}
\hline & Signifikansi \\
\cline { 2 - 2 } Ekonomi Makro & $0,000^{*}$ \\
Analisis Fundamental & $0,000^{*}$ \\
Analisis Teknikal & $0,000^{*}$ \\
\hline Croncbach alpha & 0,773 \\
\hline
\end{tabular}

Sumber: data diolah (2019)

Variabel yang digunakan dalam penelitian ini yaitu return sebagai variabel dependen, sedangkan variabel independennya terdiri dari literasi keuangan, frekuensi evaluasi, maxhold, dummy penggunaan analisis teknikal, dummy penggunaan analisis fundamental, dan durasi berinvestasi. Uji asumsi klasik yang dilakukan menunjukkan bahwa model yang digunakan telah menyebar normal, tidak mengandung multikolinearitas diantaran variabel independen dan 
secara simultan mempengaruhi return. Model summery menunjukkan bahwa $\mathrm{R}$ adjusted model adalah 0,176, artinya bahwa keragaman variabel (Y) dijelaskan oleh model sebesar 17,6 persen sedangkan sisanya dijelaskan oleh faktor lain diluar model. Hasil regresi menunjukkan bahwa variabel literasi keuangan, durasi berinvestasi berpengaruh signifikan positif terhadap return, sedangkan penggunaan analisis teknikal berpengaruh signifikan negatif terhadap return pada tingkat kepercayaan 90 persen.

Tabel 2. Hasil regresi linear berganda

\begin{tabular}{lccc} 
Variabel & $\begin{array}{c}\text { Beta Unstandardize } \\
\text { coefficients }\end{array}$ & Signifikansi & $\begin{array}{c}\text { Pengaruh } \\
\text { secara parsial } \\
(\%)\end{array}$ \\
\hline Literasi keuangan & 43391,918 & $0,041^{*}$ & 8,41 \\
Lama berinvestasi & 2003,201 & $0,031^{*}$ & 7,56 \\
Penggunaan analisis teknikal & $-983131,477$ & $0,080^{*}$ & 4,88 \\
Penggunaan analisis fundamental & 468865,317 & 0,308 & 2,16 \\
Maxhold & $-1796,293$ & 0,333 & 1,96 \\
Frekuensi evaluasi & 41173,568 & 0,719 & 0,27 \\
\hline
\end{tabular}

*Signifikan di tingkat kepercayaan 90 persen

Sumber: data diolah (2019)

\section{Keputusan Investasi}

Keputusan investasi adalah suatu kebijakan atau keputusan yang diambil untuk menanamkan modal pada satu atau lebih aset untuk mendapatkan keuntungan di masa yang akan datang atau permasalahan bagaimana seseorang harus mengalokasikan dana ke dalam bentuk-bentuk investasi yang akan dapat mendatangkan keuntungan di masa yang akan datang. Selain itu, keputusan terkait pengalokasian dana, keputusan investasi juga terkait dengan keputusan penjualan yang mempertimbangkan realisasi return.

Return sebagai tolak ukur kenaikan (indikasi keuntungan saat memegang saham tersebut) atau penurunan (indikasi kerugian saat memegang saham tersebut) saham mengharuskan penanam saham untuk mengambil keputusan. Keputusan tersebut yaitu apakah akan merealisasikan return tersebut dengan menjualnya ataukah tetap mempertahankan saham tersebut. Keputusan penjualan saham merupakan upaya profit maximization atas kepemilikan saham, yaitu upaya untuk mendapatkan return yang lebih besar pada saham yang telah dimiliki melalui penentuan waktu yang tepat untuk menjual saham tersebut. Pada keputusan penjualan investor lebih menyukai realisasi keuntungan daripada realisasi kerugian.

\section{Pengaruh Literasi Keuangan Terhadap Return}

Return yang digunakan dalam penelitian ini adalah return nilai buku, yaitu return yang diperoleh setelah saham tersebut dijual. Pengambilan keputusan menjual dan membeli saham membutuhkan literasi keuangan yang baik. Literasi keuangan yang tinggi akan memberikan kontribusi besar bagi kesejahteraan keuangan individu sebab akan memungkinkan untuk berpartisipasi di pasar keuangan dan berkinerja lebih baik di pilihan portofolio mereka (Rooij et al., 2011). Kontribusi lainnya yaitu memungkinkan untuk mengumpulkan kekayaan dalam jumlah yang lebih tinggi (Lusardi \& Mitchell, 2011), serta memungkinkan untuk mempersiapkan kehidupan setelah pensiun (Almenberg \& Soderbergh, 2011).

Penelitian terkait literasi keuangan menurut Bay et al. (2014) dapat dikategorikan menjadi tiga jenis, yaitu mengukur tingkat literasi keuangan suatu area demografik, mengevaluasi pengaruh literasi keuangan terhadap pengambilan keputusan keuangan, dan studi mengenai efek edukasi keuangan. Proses pengukuran membutuhkan pemahaman yang jelas tentang konsep literasi keuangan dan instrumen evaluasi yang tepat. Dalam hal ini penelitian eksploratif perlu dilakukan untuk membangun landasan teoritis mengenai pengembangan metodologi evaluasi literasi keuangan (Titko \& Lace, 2013).

Langkah awal dalam proses perancangan kuesioner untuk mengukur literasi keuangan yaitu dengan mengetahui komponen literasi keuangan terlebih dahulu. Sesuai dengan new literation study $(N L S)$, literasi keuangan merupakan sesuatu yang dinamis tergantung dari

Jurnal Manajemen dan Organisasi (JMO), ol. 11 No. 1 April 2020 Hal. 1-7 
kondisi sosial yang diamati (Street, 2003), sehingga definisi literasi keuangan berbeda-beda tergantung individu atau kelompok yang diamati. Perbedaan definisi literasi keuangan ini dibuktikan dalam penelitian Bay et al. (2014) pada dua kelompok berbeda yaitu siswa sekolah menengah dan komite audit. Pendidikan keuangan yang dibutuhkan oleh generasi muda adalah terkait sikap terhadap uang, sedangkan pada komite audit tidak lagi sebatas kemampuan untuk membaca dan memahami laporan keuangan fundamental, namun pada tahap kemampuan mengontekstualisasikan laporan keuangan sehingga para pembaca mudah memahaminya.

Widoatmojo (2009) mendefinisikan literasi keuangan yang dibutuhkan oleh kelompok pelaku pasar modal pada pasar saham sebagai analisis saham yang terdiri dari analisis ekonomi makro, analisis fundamental, dan analisis teknikal. Setelah mendefenisikan literasi keuangan, selanjutnya yaitu penting untuk mempertimbangkan pertanyaan-pertanyaan sesuai kompleksitasnya untuk mendeteksi kontribusi yang relevan dari setiap pertanyaan ke keseluruhan indeks literasi keuangan. (Ciemleja et al., 2014). Kompleksitas setiap pertanyaan dapat mengacu pada Taksonomi Bloom oleh Bloom et al. (1956), yaitu dengan membagi tingkat kognitif menjadi 6 yaitu knowledge level, comprehension level, application level, analysis level, systhesis level, dan evaluation level. Anderson et al. (2001) kemudian merevisinya menjadi remember, understand, apply, analyze, evaluate, dan create. Revisi Taksonomi Bloom inilah yang akan menjadi acuan dalam penyusunan instrumen pengukuran literasi keuangan.

Penelitian ini membuktikan bahwa literasi keuangan memiliki pengaruh signifikan positif terhdap return yang diperoleh oleh investor. Pada tingkat kepercayaan 90 persen literasi keuangan secara parsial berpengaruh positif sebesar 8,41 persen terhadap perolehan return investor. Literasi keuangan dalam penelitian ini didefinisikan sebagai pengetahuan terkait analisis ekonomi makro, fundamental, dan teknikal. Signifikannya variabel ini menunjukkan bahwa investor pasar modal harus memahami analisis ekonomi makro, fundamental, dan teknikal. Tingginya literasi keuangan akan meningkatkan kemampuan investor dalam pengambilan keputusan agar memperoleh return yang tinggi.

\section{Fenomena Myopic Loss Aversion}

Thaler et al. (1997) menjelaskan adanya fenomena myopic loss aversion (MLA), yaitu ketidakproporsionalan sensitifitas dengan tingkat sensitifitas yang lebih tinggi terhadap kerugian dibandingkan keuntungan apabila dikombinasikan dengan frekuensi evaluasi outcome. Pelaku pasar modal yang dapat mengakses feedback dan informasi lebih sering, akan cenderung menolak risiko. Gneezy dan Potters (1997) menemukan hal serupa yaitu bahwa semakin tinggi frekuensi pelaku pasar modal dalam mengevaluasi return, akan menyebabkan pelaku pasar modal semakin berperilaku risk averse.

Penelitian yang dilakukan oleh Gneezy dan Potters (1997) menggunakan mahasiswa sebagai sampel penelitian, sehingga mendapat protes dari Locke dan Mann (2000). Locke dan Mann (2000) berargumen bahwa setiap penelitian yang mengabaikan trader profesional kemungkinan akan diterima secara pasif sebab mereka tidak terlibat secara substansial dalam proses pembentukan harga. Penelitian ini sesuai dengan argumen Locke dan Mann (2000), yaitu bahwa fenomena MLA tidak terjadi pada investor galeri investasi Indonesia sebagai trader profesional, yang ditunjukkan dari tidak signifikannya pengaruh frekuensi evaluasi terhadap return investor. Penelitian ini memunjukkan bahwa terdapat faktor lain yang lebih berpengaruh signifikan terhadap pengambilan keputusan investasi investor, yaitu durasi investasi yang berpengaruh signifikan positif dan penggunaan analisis teknikal yang berpengaruh signifikan negatif.

\section{KESIMPULAN}

Investasi pasar modal memerlukan literasi keuangan yang baik agar dapat mengambil keputusan dengan lebih baik dan mendapatkan return yang tinggi. Adapun literasi keuangan yang dibutuhkan oleh responden adalah analisis ekonomi makro, analisis fundamental, dan analisis teknikal. Peningkatan literasi keuangan dapat dilakukan dengan mengikuti pelatihanpelatihan yang dilaksanakan oleh beberapa instansi. Pengambilan keputusan investor juga 
dipengaruhi oleh durasi investasi yaitu lamanya investor bergabung dengan pasar modal. Semakin lama investor bergabung maka pengalaman, pembelajaran, dan juga ketarampilannya juga akan meningkat sehingga akan meningkatkan kualitas pengambilan keputusannya serta meningkatkan return yang didapatkan. Pengambilan keputusan jual dan beli saham dapat dilakukan melalui analisis fundamental dan teknikal, penggunaan analisis teknikal secara signifikan mempengaruhi perolehan return, namun pengaruhnya bersifat negatif. Sehingga disarankan bahwa penggunaan analisis teknikal harus diminimalisir, dan ditunjang oleh analisis lainnya. Faktor-faktor lain seperti frekuensi evaluasi, maksimal holding, dan penggunaan analisis fundamental belum cukup terbukti secara parsial memiliki pengaruh signifikan terhadap perolehan retun pada tingkat kepercayaan 90 persen, namun tetap secara simultan mempengaruh perolehan return.

\section{DAFTAR PUSTAKA}

Almenberg, J., \& Soderbergh, J. S. (2011). Financial literacy and retirement planning in Sweden. Netspar Discussion Paper 01/2011-018.

Anderson, L. W., Krathwohl, D. R., Airasian, P. W., Cruikshank, K. A., Mayer, R. E., \& Pintrich, P. R. (2001). A Taxonomy for Learning, Teaching, and Assessing: A Revision of Bloom's Taxonomy of Educational Objectives. New York: Longman.

Bay, C., Catasus, B., \& Johed, G. (2014). Situating financial literacy. Critical Perspectives on Accounting, 25, 36-45.

Bellemare, C., Krause, M., Kroger, S., \& Zhang, C. (2005). Myopic loss aversion, information feedback vs investment flexibility. Economic Letters, 87, 319-324.

Bloom, B. S., Engelhart, M. D., Furst, E. J., Hill, W. H., \& Krathwohl, D. R. (1956). Taxonomy of Educational Objectives: The Clasification of Educational Goals. New York: Longman.

Ciemleja, G., Lace, N., \& Titko, J. (2014). Towards the practical evaluation of financial literacy: Latvian survey. Procedia - Social and Behavioral Sciences, 156, 13-17.

Gneezy, U., \& Potters, J. (1997). An experiment on risk taking evaluation periods. The Quarterly Journal of Economics, 112(2), 631-645.

Ghozali, I. (2007). Aplikasi Analisis Multivariate dengan Program SPSS. Semarang: Badan Penerbit Universitas Diponegoro.

Goldberg, J., \& Nitzsch, R. V. (2001). Behavioral Finance. Morris A, penerjemah. England: John Wiley \& Sons, LTD. Terjemahan dari: Behavioral Finance.

Locke, P. R., \& Mann, S. C. (2000). Do professional traders exhibit loss realization aversion. Working paper. Texas: Texas Christian University.

Lusardi, A., \& Mitchell, O. S. (2011). Financial Literacy: Implication for Retirement Security and the Financial Marketplace. England: Oxford University Press.

Pakpahan, K. (2003). Strategi investasi di pasar modal. Journal The Winners, 4(2), 138-147.

Pratisto, A. (2004). Cara Mudah Mengatasi Masalah Statistik dan Rancangan Percobaan dengan SPSS 12. Jakarta: PT Elex Media Komputindo.

Rooij, M. V., Lusardi, A., \& Alessie, R. (2011). Financial literacy and retirement planning in the Netherlands. Journal of Economic Psychology, 32, 593-608.

Samsul, M. (2015). Pasar Modal dan Manajemen Portofolio. Ed ke-2. Jakarta: Erlangga.

Street, B. (2003). What's new in New Literacy Studies? Critical approaches to literacy in theory and practice. Current Issues in Comperative Education, 5(2), 77-91.

Thaler, R. H., Tversky, A., Kahneman, D., \& Schwartz, A. (1997). The effect of myopia and loss aversion on risk taking: an experimental test. Quarterly Journal of Economics, 112(2), 647-661.

Titko, J., \& Lace, N. (2013). Financial Literacy: Building a Conceptual Framework. Liberec Economic Forum International Conference 2013; 2013 Sep 16-17; Sychrov, Czech Republic. Sychrove: Technical University of Liberec. hlm 585-592.

Widoatmojo, S. (2009). Pasar Modal Indonesia: Pengantar \& Studi Kasus. Bogor: Ghalia Indonesia.

Jurnal Manajemen dan Organisasi (JMO) Vol. 11 No. 1, Hal. 1-7 